\title{
Rural Indonesian Youths' Conceptions of Success
}

Rara Sekar Larasati, Bronwyn E. Wood, and Ben K. C. Laksana (2020).

The Oxford Handbook of Global South Youth Studies

Edited by Sharlene Swartz, Adam Cooper, Clarence M. Batan, and Laura Kropff Causa

Larasati, R. S., Wood, B. E., \& Laksana, B. (2020). Rural Indonesian youths' conception of success. In S. Swartz, A. Cooper, C. Batan, \& L. Kropff Causa (Eds.), The Oxford Handbook of Global South Youth Studies (pp. 1-13): Oxford Handbooks Online.

\begin{abstract}
Pierre Bourdieu is a preeminent Northern theorist whose concepts and ideas have been applied extensively in global youth studies. Yet Bourdieu has been critiqued for his assumptions of cultural homogeneity and failure to include local voices in his theory making. Therefore, the question arises: Are Bourdieu's concepts still useful for research in the Global South? Drawing on ethnographic fieldwork in a remote Indonesian village (Ngadas), this essay interrogates Bourdieu's concepts of cultural capitals in explaining young people's conceptions of 'success.' In contrast to acquisition of capital for individual distinction and competitive advantage, Ngadas youth accumulate capital in order to maintain collective harmony and sustain a gift-giving cycle (guyub rukun). This study presents an expanded understanding of capital as a collective endeavor which challenges narrow interpretations of Bourdieu in the context of Southern youth studies and suggests the need for more contextually nuanced usage of his theories. It is central to the merging theory of navigational capacities which draws on Bourdieu's notion of capitals but places emphasis on the collective nature of these capitals.
\end{abstract}

\section{Keywords}

Bourdieu capitals, Indonesian youth, collective harmony, individual distinction, reflexive sociology 
Pierre Bourdieu is a preeminent Northern theorist whose concepts and ideas have been applied extensively in youth studies in the Global North and South. Yet while his ideas appear to hold wide salience across multiple contexts, it has been suggested that Bourdieu's concepts are "as French as they are complex" (Singh \& Huang, 2013, p. 204). This draws into question the universality of Bourdieu's theories, the ways his ideas have been narrowly interpreted for predominantly Global North contexts, and the impression this gives that youth studies are speaking to youth everywhere when they are actually only referring to Northern youth (Cooper, Swartz, \& Mahali, 2018).

This essay interrogates the process of applying the concepts of Bourdieu as a Northern theorist, to a Global South context in order to examine its relevance, contributions, and oversights. The focus is on young people's conceptions of 'success'. Previous studies found that success is a highly contested concept and particular to local social, cultural, and political contexts (see, for example, Sligo \& Nairn, 2013). In addition, many studies have found value in applying Bourdieu's theory of practice (Bourdieu, 1984) as an analytical tool for examining the complex understandings of success. Many of these studies portray social, cultural, and economic capital as individual assets and resources (e.g. Raffo \& Reeves, 2000; Thornton, 1995), thus overlooking the collective nature of many of these capitals (Holland, 2008). Drawing on ethnographic fieldwork with young people from a remote rural village in Indonesia (Ngadas), this study offers an opportunity to examine the usefulness and limitations of Northern theory, such as Bourdieu's theory of capitals, for exploring young people's understandings of success in a Southern context. The essay therefore contributes to emerging critiques of Northern theory in youth studies, and also advances the understandings of 'success' from Indonesian young people's perspectives.

\section{Bourdieu, Colonialism, and Global Knowledge Production}

Pierre Bourdieu is arguably one of the most cited and applied theorists in youth studies (France, 2016; France \& Roberts, 2014). His work has been extensively used in education, as well as transition studies and numerous other fields involving youth. Yet, despite this status, questions have been raised about the universality of his theories and their 
applicability beyond the Northern metropole (Connell, 2007; Free, 1996; Said, 1989; Singh \& Huang, 2013). This critique of Bourdieu has given rise to more general concerns about the transnational portability of theories and ideas from the Global North.

Broadly, there are three responses to Bourdieu's theories in global contexts. First, there is a group who argue that Bourdieu has nothing to offer in this area because his work was Eurocentric, failed to recognize the impact of colonialism and racism (Free, 1996; Said, 1989), and that he was part of the colonial regime. Others say that he failed to include voices of local people in his work, citing as one example his work with the Kabyle in Algeria (Connell, 2007; Free, 1996; Singh \& Huang, 2013), and that the concepts he produced are overly complex in keeping with the French sociological tradition. Such authors view Bourdieu as part of a set of Northern Orientalist theories that portray nonwestern societies as static and homogenous and overlook global Western domination. His attempt to create a "universally applicable tool kit" (Singh \& Huang, 2013 p. 44) also failed to include local and Indigenous voices in this theory.

A second response is by those who argue that his thinking on colonialism "remains underexplored" (Go, 2013, p. 50) and that Bourdieu had developed a theory of colonization that shaped his subsequent work significantly, but this has been overlooked (Go, 2013; Robbins, 2003). For example, Go (2013, p. 51) argues that "Bourdieu articulated a systematic theory of colonialism that entailed insights on colonial social forms and cultural processes and contained seeds for some of his later more well-known concepts and ideas like habitus, field, and reflexive sociology."

While Bourdieu did not position himself with the far-left critics of French colonialism (such as Fanon and Sartre), he was not pro-Empire. He supported national independence and criticized the reformists, arguing that reform was futile as colonialism had to go. Bourdieu's understandings of colonialism included a critique of anthropological studies for imagining that native populations were untouched by colonial rule and he attacked modernization theory for failing to consider the extent to which colonialism shaped the economy as well as social relations and dispositions (Go, 2013). He also 
recognized that the ethnography he was involved in was caught up in maintaining colonialism as it had long been involved in "supplying the colonial power with the means to establish itself” (Bourdieu, 1963/1979, p. 264).

Lastly, there is a group of responses to Bourdieu's research with which the authors of this essay feel closer affiliation. This response highlights Bourdieu's focus on "reflexive sociology" as a pivotal underpinning of both his methods and theory, captured predominantly in his book with Lois Wacquant, Reflexive sociology (Bourdieu \& Wacquant, 1992). This position sees Bourdieu's work primarily as "a method of enquiry, rather than a completed theoretical edifice" (Harker, 1990, p. 99). His aim in the creation of concepts such as 'habitus' and 'capital' was to develop a supple, dynamic, adaptable set of concepts to explain human perceptions, dispositions, and actions (Bourdieu \& Wacquant, 1992), rather than a fixed universal theory. His argument is that there is a need for 'supple' and 'adaptable' concepts which can be applied and reapplied in differing theoretical and situational frameworks and be tested again and again (Bourdieu \& Wacquant, 1992). His reflexive position about knowledge production also extended to knowledge claims as "knowledge must lay bare the sociological conditions" (Go, 2013, p. 66) of its existence and render visible the "unthought categories of thought which delimit the thinkable and predetermine what is actually thought"' (Bourdieu, 1990, p. 178). This approach conveys a much more tentative approach to knowledge production and an ongoing awareness of blind spots and limitations, which in themselves require ethical consideration (Robbins, 2003).

\section{Bourdieu, Reflexive Sociology, and Its Relevance to Global South Youth Studies}

This reflexive approach of Bourdieu informs the understanding of the application of his work in Global South youth studies. While acknowledging many of the limitations of his theories for universal application (which was never Bourdieu's intention), it is still interesting to test his concepts in new settings alongside "concepts and agendas of local concern" (Cooper et al., 2018, p. 11). The intention is to generate more relevant theories and concepts for youth studies in the Global South, while also critiquing the limitations of a universal application of Northern theories in Southern contexts, and, most importantly, discovering more contextually nuanced Southern theories and concepts that best represent 
the Global South in global dialogues. Engaging critically with Northern theories is another way of recognizing the domination and imbalance of power relations in knowledge production as well as looking for an opportunity to "seek for intellectual ruptures" (Reiter, 2018 , p. 318) to provide new and equal spaces for Southern theory to contribute to Global theory. In this study, Bourdieu's theory of capitals is used to explore youth frameworks of 'success' drawing on fieldwork in Ngadas village, a desa wisata adat [official tourism and traditional cultural village] located in East Java, Indonesia, also known as part of the Tengger people (Hefner, 1985).

\section{The Young People of Ngadas}

Rural sociologist Ben White, who has been studying rural youth in Indonesia for decades, notes that many young rural Indonesians face critical challenges such as underemployment, landlessness, and precarious farming. Less than half the farmers in Indonesia own their land, there are high rates of urbanization, and there is a low rate of participation in postprimary education which leads to fewer opportunities for rural youth to pursue employment outside the village (AKATIGA \& White, 2015). However, Ngadas is an exception to this pattern because young people from Ngadas are known for high rates of land ownership, successful potato farming, and low rates of urbanization (but also low participation in formal education). This study showed that young people in Ngadas preferred to stay in the village not only because of economic assets but also because of the customs, rituals, and values (adat) that play an integral part in shaping young people's ways of "being in the world" (Bourdieu, 2002, p. 135) and their ways of seeing the world. Thus a closer inquiry into how young people in Ngadas view 'success' provides a way to explore the significance of specific social, economic, and cultural aspects that shape rural young people's understandings, and perhaps, bring to the fore alternative local understandings of rural youth success as a "critique of developmentalism" (Tirtowalujo, 2016, p. 23) and the modernization project in Indonesia as well as in other Southern contexts.

\section{Methodology and Theory}

The study used a suite of ethnographic data collection methods in Ngadas in 2017. These involved focus group discussions (or klumpukan, a local term for a gathering for a particular 
purpose, usually in the form of a group discussion), auto-driven photo-elicitation followed by individual in-depth interviews with six participants aged 16 to 17 years old, semistructured individual interviews with four village leaders, and participant observation. The auto-driven photo-elicitation activity enabled the participants to answer a research question by taking photographs. Six participants used disposable cameras (each containing thirtynine frames) over the course of two weeks to take photos of what 'success' means to them. During interviews, participants explained the significance of their photographs in relation to their understanding of success. Participant-produced images in photo-elicitation were used to complement Northern theory, such as that of Bourdieu, because this provided greater potential for participatory and emancipatory knowledge production during fieldwork, and stimulated greater agency for youth participants.

To unpack young people's conceptions of success in Ngadas, Bourdieu's theory of capitals was used to interrogate the practices of young people to achieve success and explore the capitals and habitus within Ngadas as the field. Bourdieu's theory of practice-in particular his concepts of capital, habitus, and field-is a useful framework for this research. Using this conceptual triad allowed the research to illuminate "a way of understanding the world" (Reay, 2004, p. 439) that speaks to both the complex and rudimentary aspects of Ngadas youths' understanding of success. The adoption of a Bourdieusian framework was central in this research as it has the potential to deepen "one's understanding of the interrelationships between objective structures and personal lived experiences" (Hardy, 2014, p. 249) in keeping with Bourdieu's goals of reflexive sociology.

In Distinction (1984), Bourdieu outlines his theory of practice in the following equation:

$$
[(\text { habitus })(\text { capital })]+\text { field }=\text { practice }(\text { Bourdieu, } 1984, \text { p. 101 })
$$

This equation describes how an individual's actions and dispositions (practices) reflect the interplay of capital, habitus, and field. In this research, capital emerged with distinction, in other words, emerged with a symbolic value in the field. A field is essentially the social space where interactions, transactions, and events between social agents (individuals and 
groups) operate (Bourdieu, 2005, p. 148). A field possesses its own regulative principles and values, thus delimiting a "socially structured space in which agents struggle, depending on the position they occupy in that space either to change or to preserve its boundaries and form" (Bourdieu \& Wacquant, 1992, p. 17). In this study, Ngadas was viewed as the field for young people's success. Ngadas, its customary practices (adat), and its relational configuration, dictates both the social and spatial boundaries that "imposes on all the objects and agents which enter in it" (Bourdieu \& Wacquant, 1992, p. 17). Due to the uniqueness of Ngadas as a rural village, Bourdieusian analysis of this field recognizes that understandings of success were likely to be shaped by the forces competing for preference in this sociospatial site, underpinned by cultural notions of adat. As a field, Ngadas is simultaneously a space of struggle which "gives any field a historical dynamism and malleability that avoids the inflexible determinism of classical structuralism" (Bourdieu \& Wacquant, 1992, p. 18) and a space where every agent acts according to his or her capitals, habitus, and personal history, which stem from the contestations of his or her dispositions and positions that may even be contradictory (Bourdieu, 2002). However, as the point of entry to understanding success was from the perspectives, actions, and experiences of young people (their practices), an inverted version of Bourdieu's theory of practice better reflects the approach undertaken in this study:

$$
\text { Practice }=[(\text { habitus })(\text { capital })]+\text { field }
$$

Thus, Bourdieu's theory of practice provided a useful lens for examining and explaining which forms of capital and habitus emerge with distinction in Ngadas and why they are distinctive for young people's success. In particular, this approach became important in helping understand how distinction, or what holds symbolic value in the field of Ngadas, was not necessarily a matter of difference, but a matter of belonging and inclusion in the community.

From the study in Ngadas, notions of success were articulated through three main practices which were all informed by the adat, or customary practices: work practices (and 
their relation to educational practices), familial and relational practices, and religious practices.

\section{Rural Ngadas Youths and 'Success' as Social Capital}

Based on the photographs and conversations shared by participants, young people's perceptions of, and practices for success were significantly shaped by their familial habitus, community habitus, or doxa, and religious habitus, that sit under the umbrella of the adat in Ngadas. In these practices, social capital emerged as the capital with the greatest symbolic value as it provided meaning for both the self and the community through reciprocity and good relationships within the community. Interviews revealed the significance of social capital as being necessary for 'success' of young people in Ngadas. For example, Ida (a pseudonym) was a young girl who helped in her grandmother's warung or small shop and phone credit top-up business because she wanted to work for her family. In the study, Ida took a photo of her sister at her grandmother's warung and explained what she wanted to do with her income as follows:

Ida: This warung can provide, like an additional job. More money aside from farming right, and we can have extra income from home too. And then the money can be used to buy this, and that! [laughs]

Interviewer: So, the warung. . . You run it? Does the money go to you?

Ida: No, of course. [It goes to] My grandmother.

Interviewer: But for phone credit business, that's you?

Ida: Phone credit, that's me.

Interviewer: For phone credit, what is the average income for you recently?

Ida: $\$ 20$ per week.

Interviewer: From $\$ 20$, how much do you save?

Ida: $\$ 15$, sometimes ...

Interviewer: Once you save a lot, does your grandmother keep it?

Ida: If I have a lot in my savings, it will be kept by my grandmother. My dream is, when we have the Sadranan ritual, I want to buy clothes for my grandmother, my mom and my little sister. From my own income. Well, I'm still learning, right. . . . Still learning, so if I 
have a little bit of money, I want to buy [clothes] for them. .. . Later if I become successful from farming, I will take them traveling.

Ida emphasized that the importance of success from work was not just for herself, but in order to make her family happy:

Ida: Hmm ... . Yeah, well [my grandmother] always prays for the best for me. Hoping that I will become a successful person. Hoping that I could take her traveling, before she gets old. That's what she said.

Interviewer: Traveling, where to?

Ida: Where to mbak [older sister - a sign of respect]? Not too fancy really. I just want to find happiness like ... [taking her] fishing, that's her hobby! Grandmother and grandfather's [hobby]. And then, maybe just go down [the hill to the local region below] . . . And just go on recreations, really.

Interviewer: So . . it's important . . .

Ida: To make your parents ... happy.

The above examples show how success through work was perceived as not only the accumulation of economic capital but also was underpinned by filial responsibilities, reciprocal caregiving such as berbakti (to be devoted to our parents), balas budi (to reciprocate or return a favor), and the desire to make one's parents and family happy. It also appeared that work practices for the young people in the study were able to achieve symbolic meaning or success when they were aligned with communal reciprocity, a gift system that underpinned the exchange of capitals rather than an emphasis on personal gain.

A further example illustrating the importance of both reciprocity and communal responsibilities is the concept of guyub rukun. This term is rather difficult to translate but means 'togetherness in solidarity and peace/harmony'. Guyub rukun was used many times during interviews and focus groups (klumpukan) with youth participants, especially when participants were elaborating on what success meant for Ngadas as a society. Tono (also a pseudonym), for example, a 16-year-old farmer, found it very difficult to separate the idea of personal success from the success of Ngadas as a whole. "Rame ing gawe, sepi ing pamrih [To work hard, to help others unconditionally]," he said, quoting a saying of Buddha Jawa 
Sanyata that suitably represents his understanding of success. "It's like, gotong royong [mutual cooperation]. I think that is also success. To help each other. Guyub rukun."

Guyub rukun therefore is one of the key underlying values that holds the Ngadas community together and it is reproduced through the practice of rituals and ceremonies (in other words, adat). This was especially evident in how rituals and ceremonies affect and are "affected by village social and economic organization" in which "the requirements and consequences of ritual practice extend across social fields" (Hefner, 1985, p. 216).

The betek (festival laborers) ritual, for example, also demonstrates the importance of maintaining good social relationships. The participation of community members in Ngadas at each other's festivals as laborers is integral to the social and economic organization of Ngadas as they are not only ritual exchange partners that sustain the ritual reproduction in the village, but they also serve as a form of social capital that reaffirms or even amplifies the social position of the festival hosts in the society. The abundance of betek determines the success of one's ceremony (Hefner, 1985). In short, this example shows how guyub rukun, as part of adat values, maintains the adat, while at the same time, adat (through rituals, ceremonies, and exchange systems) perpetuates Ngadas as a cultural community, or a desa adat.

The embeddedness of adat in these practices also illustrates a strong connection between young people's success and a sense of belonging and place. Ngadas for young people becomes a thick place that gives a sense of "fixity and rootedness to family, place and a way of life" that is manifested in everyday practices and "a longing to transmit to their offspring practices that nurture belonging" (Cuervo \& Wyn, 2017, p. 10). In essence, understanding success for young people in Ngadas was inseparable from understanding their sense of belonging, sense of community, their place in the world, and their being.

\section{Interrogating the Utility of Bourdieu for the Global South}

This study has affirmed the utility of many aspects of Bourdieu's theories, but also highlighted slightly different emphases than how Bourdieu's forms of capital have generally 
been interpreted. For example, Bourdieu (1986) discusses how social capital can be worked for by an individual to gain status within a group or community through the network of social connections a person can mobilize. In this study, participants rarely talked about individual gain - their focus was on communal gain — through the maintenance of adat. For young people in Ngadas, the type of social capital that emerged with distinction and held symbolic value in the field of Ngadas was strongly shaped by adat (i.e., through customs on land ownership, values on filial piety, and rituals for maintaining harmony). In other words, their success practices were "underpinned by a form of social capital that is founded on reciprocity or a gift exchange, which is embedded within and shaped by adat, and in turn also serves to maintain adat" (Larasati, 2018, p. 3). This draws attention to the significance of gift giving or reciprocity as a cultural way of maintaining not only adat, but also the individual's sense of being, social cohesion, and cooperation in society, especially in the face of social changes.

Bourdieu (1986, p. 24) also claims that "economic capital is the root of all other types of capital." However, in this study, themes of communal commitment, responsibility and sustainability were much stronger than individual economic gain. For young people in Ngadas, success is a form of illusio, a "way of being in the world, of being occupied in the world" (Bourdieu, 2002, p. 135, emphasis in original) that generates a sense of meaning and purpose to one's life. Participants showed that an understanding of success is an understanding of being as belonging with, and for, others. Success is achieved through the accumulation of capital, particularly social capital that could be transformed into a symbolic capital: "the acquisition of a reputation for competence and an image of respectability and honorability" (Bourdieu, 1984, p. 291). This symbolic capital was achieved through work, familial and relational, and religious practices that are embedded with adat and are situated in the field of Ngadas.

These findings challenge some of the dominant interpretations of social capital found in Global North youth research that have tended to interpret social capital as a form of exchange or accumulation for individual gain. These fall short in shedding light on the type of gift giving proposed in this study where social capital was practiced as a form of relational 
exchange founded on reciprocity or a gift exchange system that also defined belonging and inclusion in the field for young people in Ngadas. Following this logic, social capital was a symbolic capital that cultivated one's illusio, which proposes a much more relational understanding of success as 'being and belonging with and for others.' The reason for this, to quote one participant, Tono, is because success in Ngadas is: "Rame ing gawe, sepi ing pamrih [to work hard, to help others unconditionally]. It's like, gotong royong [mutual cooperation]. I think that is also success. To help each other. Guyub rukun [togetherness in harmony]."

An understanding of success through the lens of social capital underpinned by reciprocity or a gift exchange cycle, a sense of belonging and community, and a sense of being or illusio pose critical questions about the complexities, tensions, exchanges and negotiations in the everyday practices that underpin and enable young people's aspirations for success and well-being. Thus success that is underpinned by a gift-giving cycle presents a more complex understanding of the field as a site of struggle, particularly of the tensions behind both inclusion and exclusion (and who belongs to Ngadas and who does not) and how the field essentially helps define the practice of reciprocity as a practice of success. The case of young people in Ngadas shows that success is not just a matter of economic exchange that could easily be replaced, uprooted, or as it were, upgraded to different contexts. Success is a matter of belonging, a matter of being, and success concerns individuals outside oneself. It illuminates the complex relations regarding what brings meaning to life and what it means to be human and how experiences of belonging also include an exclusionary element that requires emotional labor and work to maintain a status of inclusion within a field.

\section{Conclusion}

Utilizing Bourdieu's conceptual triad of capital, habitus, and field, the study finds that kin relationships, processes of land transfer, and the solidarity of community commitments form a compelling explanation of what counts for success for Ngadas youth, and indeed, for future decision making. For Ngadas youth, capital was gained for the purpose of maintaining greater collective harmony and sustaining a gift-giving cycle (guyub rukun). The 
case of young people's success in Ngadas presents an understanding of capital as a collective pursuit which gives young people a sense of purpose that is gained from investing in social relationships. Young people in this study showed how their understandings of individual success were inherently linked to the success of Ngadas as an economic, social, and cultural community, and the sense of being and belonging with and for others within this place. Thus their understanding of success is inherently connected to the collective success of Ngadas and, simply put, it is to understand success as social. This is a sharp contrast to many studies on Bourdieu's capital which center on the acquisition of capital for primarily individual distinction, economic gain, and competitive advantage.

Returning to the original question-are Bourdieu's theories of relevance to the Global South - the answer is 'yes, but ...'. Yes-the study affirms that Bourdieu's theories have some value and shed light on aspects of how young people were defining and practicing success. But - the traditional interpretations of his capitals (individualistic, economic, competitive) are very limiting as they fail to comprehend more collective notions of success, and the significance of customary practices, which contradict many selfinterested and competitive forms of capital. Understanding Bourdieu's theories as a method rather than a set of fixed entities allows this study to not only contribute new depth to Bourdieu's original conceptions but also question the individualist foundations of Global North theories. By exploring locally derived concepts and practices from the Global South, such as guyub rukun, it provides a much richer sense of why young people were contributing to and mobilizing their social networks for both individual and collective gain. The practice of guyub rukun therefore expands Bourdieu's original interpretation of social capital, and critically engages with its limitations as a global narrative of all young people. These much more relational, intergenerational, and communal understandings can also serve to broaden and enrich understandings of not only capital but also success, and what Swartz terms navigational capacities (elsewhere in this volume) in both the Global North and South.

Seeing richer and more complex understandings of Bourdieu also links back to what Harker (1990) sees as the understanding of Bourdieu's theories of capital as a method of inquiry rather than a fixed theoretical framework. Understanding the limitations of 
methods, concepts, and theories of the Global North as a universal framework provides opportunities for the Global South to develop its own contextualized methods and theoretical frameworks in understanding its own world. This challenges Global North theories that dominate the imagination of social scientists and precludes seeing the Global South merely as a 'data mine' (Connell, 2007, p. 68).

To conclude, this study has illustrated how Bourdieu's capitals require reinterpretation and reimagining for the Global South in much more contextually nuanced ways. In the absence of this, the unconscious bias in much of the world's youth studies is perpetuated. Much deeper interrogation of Northern theorists is needed alongside the growing assertion of theory, concepts, and research from the Global South to address the geopolitical inequalities of knowledge production and consumption.

\section{References}

AKATIGA., and White, B. (2015, April 7). Would I like to be a farmer? Inside Indonesia 2015 (120). Retrieved from http://www.insideindonesia.org/would-i-like-to-be-afarmer-2.

Bourdieu, P. (1979). Algeria 1960. Cambridge University Press. (Original work published 1963).

Bourdieu, P. (1984). Distinction. Cambridge University Press.

Bourdieu, P. (1986). The forms of capital. In J. G. Richardson (Ed.), Handbook of theory and research for the sociology of education (pp. 81-93). Greenwood.

Bourdieu, P. (1990). In Other Words: Essays Towards a Reflexive Sociology. Stanford University Press.

Bourdieu, P. (2002). Habitus. In J. Hillier \& E. Rooksby (Eds.), Habitus: A sense of place (pp. 27-34). Ashgate.

Bourdieu, P. (2005). The social structures of the economy. Polity.

Bourdieu, P., \& Wacquant, L. (1992). An invitation to reflexive sociology. University of Chicago Press. 
Cuervo, H., \& Wyn, J. (2017). A longitudinal analysis of belonging: Temporal, performative and relational practices by young people in rural Australia. Young 25(3), 219-234.

Connell, R. (2007). Southern theory: The global dynamics of knowledge and social science. Allen and Unwin.

Cooper, A., Swartz, S., \& Mahali, A. (2018). Disentangled, decentred and democratised: Youth studies for the Global South. Journal of Youth Studies 22(1), 29-45. doi:10.1080/13676261.2018.1471199

France, A. (2016). Understanding youth in the global economic crisis. Policy Press.

France, A., \& Roberts, S. (2014). The problem of social generations: A critique of the new emerging orthodoxy in youth studies. Journal of Youth Studies 18(2), 215-230. doi:10.1080/13676261.2014.944122

Free, A. (1996). The anthropology of Pierre Bourdieu: A reconsideration. Critique of Anthropology 16(4), 395-416. doi:10.1177/0308275X9601600405

Go, J. (2013). Decolonizing Bourdieu: Colonial and postcolonial theory in Pierre Bourdieu's early work. Sociological Theory 31(1), 49-74. doi: $10.1177 / 0735275113477082$

Harker, R. (1990). Bourdieu-Education and reproduction. In R. Harker, C. Mahar, \& C. Wilkes (Eds.), An introduction to the work of Pierre Bourdieu: The practice of theory (pp. 86-108). Macmillan.

Hardy, C. (2014). Social space. In M. Grenfell (Ed.), Pierre Bourdieu: Key concepts (pp. 229-249). Acumen Publishing.

Hefner, R. W. (1985). Hindu Javanese: Tengger tradition and Islam. Princeton, NJ: Princeton University Press.

Holland, J. (2008, September). Young people and social capital: What can it do for us? In Families \& Social Capital Research Group London South Bank University. Retrieved from http://www1.lsbu.ac.uk/ahs/downloads/families/familieswp24.pdf

Larasati, R. S. (2018). Success as social: Exploring young people's understandings of success in rural Java. (MA thesis). University of Wellington.

Raffo, C., \& Reeves, M. (2000). Youth transitions and social exclusion: Development in social capital theory. Journal of Youth Studies 3(2), 147-166. 
Reay, D. (2004). It's all becoming a habitus: Beyond the habitual use of habitus in educational research. British Journal of Educational Studies 25(4), 431-444.

Reiter, B. (2018). Constructing the pluriverse: The geopolitics of knowledge. Duke University Press.

Robbins, D. (2003). The responsibility of the ethnographer: An introduction to Pierre Bourdieu on "colonialism and ethnography." Anthropology Today 19(2), 11-12. doi:10.1111/1467-8322.00176

Said, E. (1989). Representing the colonized: Anthropology's interlocutors. Critical Inquiry 15(2), 205-225.

Singh, M., \& Huang, X. (2013). Bourdieu's lessons for internationalising Anglophone education: Declassifying Sino-Anglo divisions over critical theorising. Compare: A Journal of Comparative and International Education 43(2), 203-223. doi:10.1080/03057925.2012.687128

Sligo, J., \& Nairn, K. (2013). Children's' understandings of success. In N. Higgins \& C. Freeman (Eds.), Childhoods: Growing up in Aotearoa New Zealand (pp. 235-248). Otago University Press

Thornton, S. (1995). Club culture: Music, media and subcultural capital. Polity.

Tirtowalujo, I. (2016). Narratives of success: Indonesian rural youth as success subjects in a schooled society. (Doctoral dissertation). Michigan State University.

\section{Endnotes}

\footnotetext{
i Buddha Jawa Sanyata can be regarded as a hybrid religion between the theology of Jawa Sanyata with roots in an ancient Javanese belief called kejawen, and the terminology and philosophy of Buddhism.
} 